\title{
RECENT VS. HISTORICAL SEISMICITY ANALYSIS FOR BANAT SEISMIC REGION (WESTERN PART OF ROMANIA)
}

\author{
EUGEN OROS - Senior Researcher, PhD, National Institute for Earth Physics, e-mail: eugeno@infp.ro \\ MIHAI DIACONESCU - Senior Researcher, PhD, National Institute for Earth Physics, e-mail: diac@infp.ro
}

\begin{abstract}
The present day seismic activity from a region reflects the active tectonics and can confirm the seismic potential of the seismogenic sources as they are modelled using the historical seismicity. This paper makes a comparative analysis of the last decade seismicity recorded in the Banat Seismic Region (western part of Romania) and the historical seismicity of the region $(\mathrm{Mw} \geq 4.0)$. Four significant earthquake sequences have been recently localized in the region, three of them nearby the city of Timisoara (January 2012 and March 2013) and the fourth within Hateg Basin, South Carpathians (October 2013). These sequences occurred within the epicentral areas of some strong historical earthquakes $(\mathrm{Mw} \geq 5.0)$. The main events had some macroseismic effects on people up to some few kilometers from the epicenters. Our results update the Romanian earthquakes catalogue and bring new information along the local seismic hazard sources models and seismotectonics.
\end{abstract}

Keywords: seismicity, magnitude, macroseismic intensities, seismotectonics, seismic hazard

\section{Introduction}

The seismicity of the western territory of Romania, often called "Banat Seismic Region" (BSR) is characterized by obvious clusters of epicenters that are grouped within two major seismogenic zones, Banat Seismogenic Zone (BSZ) in the North and Danube Seismogenic Zone (DSZ) in the South, respectively, as they are defined and characterized by [1-3]. The seismicity of BSR is a crustal one $(\mathrm{h}=1-35 \mathrm{~km})$ being controlled by several faults systems that can be reactivated under particular stress conditions.

To our best knowledge, only several papers on the seismicity of the studied region have been elaborated and/or published last decade. Most of these papers refer to seismicity and seismic sequences [4-12], seismicity and seismic hazard [1-3, 13, 14], the relationship between seismicity, geology, tectonics, stress field and geodynamics features [5, 15].

We also found out in the literature some older works on the same topics [16-27, 29]. All these papers brought significant and coherent data to the knowledge and understanding of the earthquakes in the region. Thus, the first paper published by [16] described two major patterns of the earthquakes manifestations within BSR, defining them as the "Banat earthquakes" grouped in the North and "Danube earthquakes" located in the South. The seismogenic zones recently modelled by [3] generally correspond to this classification. Then, [17] and [18] used geological and geophysical data to achieve a detailed seismotectonic zoning of the Romanian territory and [26] emphasized significant seismotectonic details in the region on the seismicity and neotectonic activity relationship.

Using a grid search technique and a detailed tectonic map of BSR [21-24] computed a "geographical index of seismicity" or "tectonic stream distribution" to define the three zones with high seismic potential. Their results supported the modern macroseismic zoning of the region which was included in the Romanian standard and remained unchanged until present.

Later [14] made a synthesis based on the last Regional Catalogue (CAPAB) published by [28] and described four zones where the strongest earthquakes with Imaxobs=VIII EMS have been 
located. Two of them develop within Western Plain of Romania between Arad-Sinnicolau Mare and Banloc-Timisoara, respectively. The other two are located in the South Carpathian Orogen, known as Oravita-Moldova Noua and Mehadia-Orsova seismic zones. [14] have described three time-dependent seismic sequences for BSR: i) Foreshock-Main shock-Aftershocks, ii) Main shock-Aftershocks and iii) Swarms. They also speculate some long-time behavior of the seismic activity with its possible migration between the North and the South seismic zones.

Recently, [2] compiled the most complete earthquakes catalogue located within BSR and its surroundings and he modeled the newest seismic zoning of RSB using a comprehensive dataset on geology, geophysics, tectonics and seismicity. He defined three zones of particular seismicity that correlate to the geotectonic units on $\mathrm{Mw} \geq 5.3$ (Io $\geq$ VII-VIII EMS) earthquakes distribution basis: i) the Northern Zone with Sinnicolau Mare-Arad epicentral areas, ii) the Central Zone having two epicentral areas (Timisoara and Banloc-Voiteg) and iii) the Southern Zone inside which he defined Oravita-Moldova Noua and Mehadia-Orsova epicentral areas. The author described also a new seismo-active zone within Poiana Rusca Mts - Hateg Basin - Bistra Valley area.

The main objective of this paper focuses on i) the investigation of the seismic activity recorded in the region over last decade, especially the past five years when several events produced macroseismic effects, and ii) performing a comparative analysis with the strong historical seismicity models and local seismic hazard sources. We also analyzed and compiled all available databases to update the regional parametric catalogue of earthquakes for Banat (CAPAB) developed by [3].

\section{Data and processing}

We compiled a new up to date earthquakes catalogue using seismic bulletins and catalogues. Two earthquakes catalogues, CAPAB by [3, 28] and ROMPLUS (updated version from www.infp.ro) furnished hypocentral parameters of all earthquakes used in the paper. For many significant earthquakes we also collected primary seismological data, like waveforms, travel times, polarities, amplitudes recorded by:

i. the Romanian Seismic Network

ii. national and international seismological services, such as for example CSEM (www.emsc-csem.org), GFZ-GEOFON (www.geofon.gfz-potsdam.de/waveform), ISC (www.isc.ac.uk) and Serbian Seismological Survey (www.seismo.gov.rs).

The core of the new database is CAPAB Regional Catalogue compiled for 1443-2006 period by [3]. All seismic events recorded since 2007 have been imported from ROMPLUS Catalogue and ISC Bulletins. We relocated all imported hypocenters using a local velocity model [2] and the Seisan free software package [30] to respect the procedure used for CAPAB_1443-2006.

The final database contains a generic magnitude $M$ that is referring to Mw until 2006 and mainly MD between 2007 and 2013. This magnitude should not be used for quantitative investigation of seismicity.

A complex problem for seismicity studies appeared since 2000 when the Romanian Seismic Network systematically developed and very sensitive seismic sensors have been installed all over the Romanian territory. As a direct consequence, ROMPLUS included a large number of seismic events that could be explosions and so, these events can contaminate the natural phenomena under investigation. The same problem could appear in ISC bulletins from the data supplied by the Seismological Service of Serbia.

We investigated the compilation between 1988-2013 to identify and eliminate, as it is possible, all this type of events. The charts presented in Fig. 1 show anomalous values of some relevant parameters for highlighting the events suspected to be explosions. Thus, we simply could notice: 
i. a very sharp increase in the cumulative number of events after 2005 without any significant increase in seismic moment;
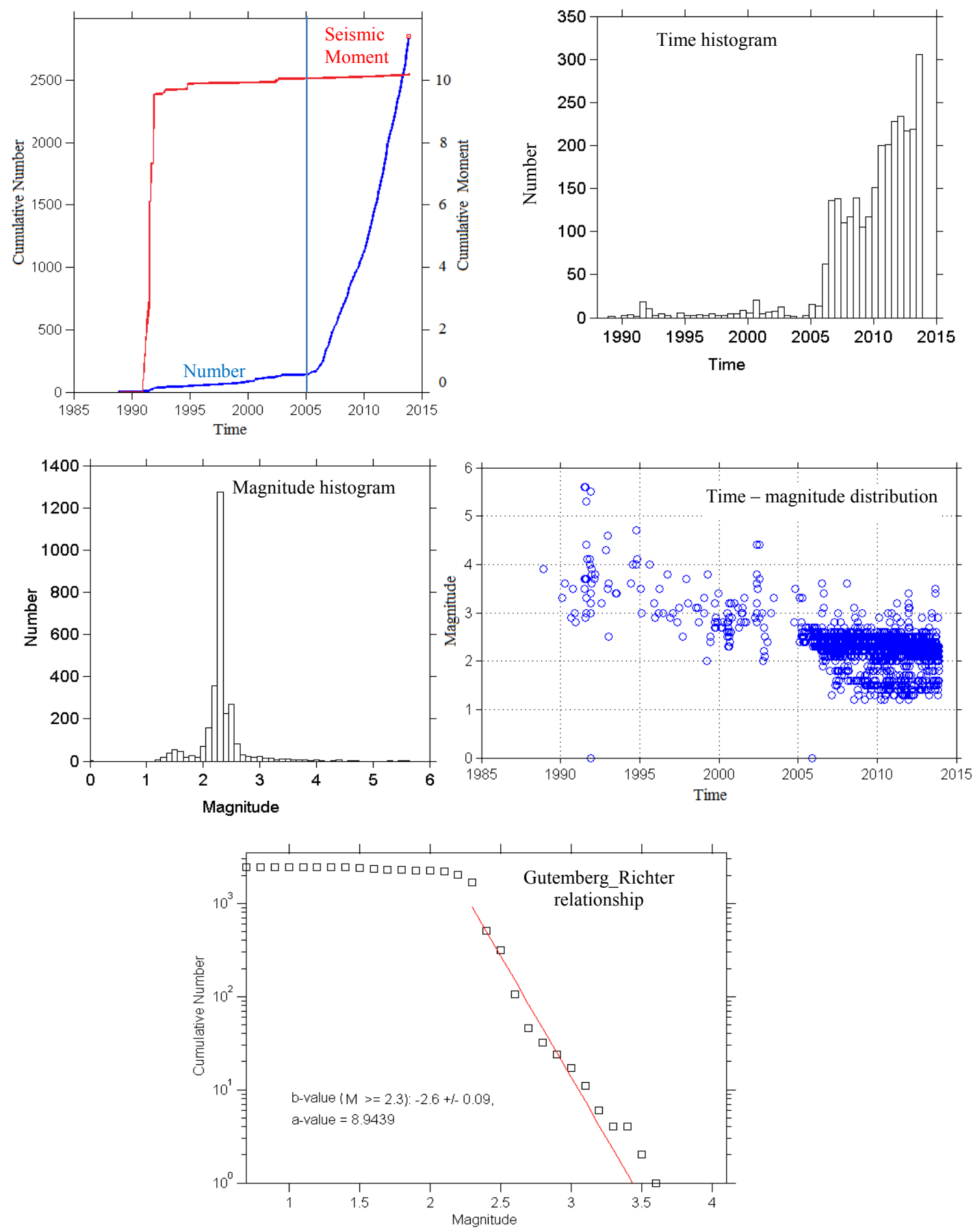

Fig. 1 - ROMPLUS catalogue and ISC bulletin compilation (1988-2013): magnitude analysis. All distributions show anomalous values that support inclusions of explosions between 2006 and 2013. The entire aftershocks series of the strongest ( $M=5.5-5.6)$ earthquakes occurred in Banloc (12.07.1991 and 02.12.1991) and Mehadia (18.07.1991) zones are not included.

i. a large number of the events with $\mathrm{M}=2.3$ between 2006 and 2013,

ii. a very sharp increase in the number of events with $\mathrm{M}=2.3-2.5$ since 2006,

iii. a large value of the $b$ coefficient of Gutemberg-Richter relationship ( $b>1.5)$.

To localize the zones with possible quarry and/or mining blasts we firstly investigated the ratio of daytime to nighttime number of events as an efficient technique described by [31]. High values of this ratio estimate the possible distribution of explosions in the region. We applied this 
technique using a grid search of $10 \times 10 \mathrm{~km}$, sample size $\mathrm{N}=100$ and a daytime interval between 7 and 15 hours. Finally, we removed 1386 of the 2847 (56\%) events recorded during 2007-2013. Most of them were located in Apuseni Mts, Poiana Rusca Mts and Moldova Noua areas (Fig. 2). However, we applied additional criteria before eliminating the suspected explosions: first polarities of $\mathrm{P}$ wave (direct $\mathrm{P}$ waves from explosions expose compressions), waveforms, magnitude, information about the locations of quarries, mines, etc. We kept in the final catalogue more events located in areas Siria-Arad, Deva-Hateg and Moldova on the direct $\mathrm{P}$ wave polarity and spatial distribution of epicenters criteria basis. We obtained the histograms and the maps shown in Fig. 1 and Fig. 2 using Zmap software [32].

The new updated regional catalogue elaborated for BSR by [3] contains 8690 entries of which 1080 occurred between 2007 and 2013.

\section{Results and discussions}

Figure 3 displays the distribution of seismic events identified and localized in BSR between 1 January 2007 and 31 December 2013. Even there is a trend of dispersion of the epicenters within entire region we notice several obvious clusters. Four significant earthquakes, defined here as events with macroseismic effects, occurred in the region over last years (Table 1).
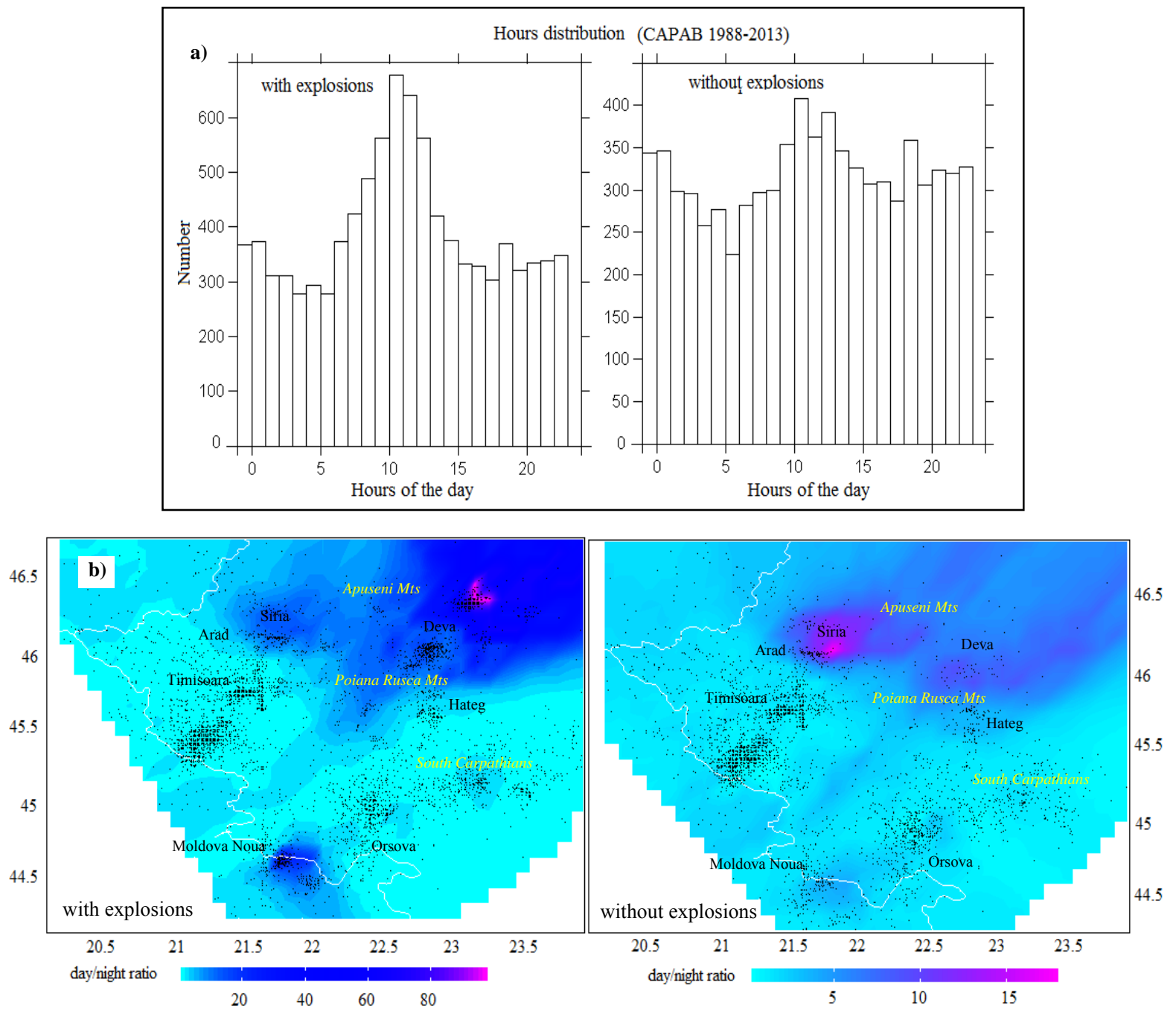

Fig. 2 - Database analysis (1988-2013): quarry identification using the ratio of daytime to nighttime number of events. Hourly histograms of the number of events (a) and the 2D distributions of the ratio of daytime to nighttime number of events (b) obtained with and without suspected explosions. 

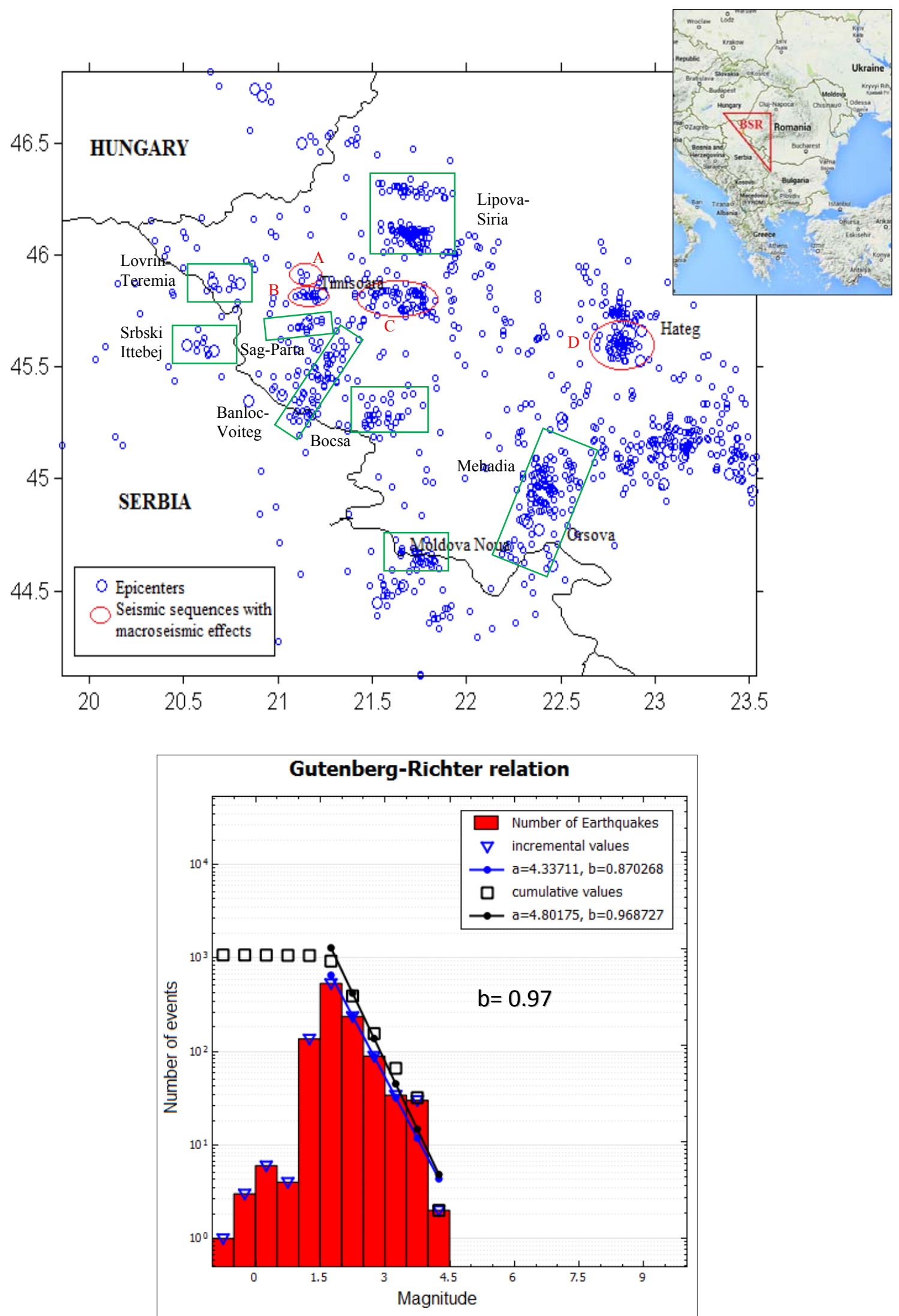

Fig. 3 - a) Banat Seismic Region (BSR): Map of epicenters without explosions (1081 events, period: 2007-2013). Red circles define the four significant seismic sequences (main event with macroseismic effects) located within Timisoara-Sanandrei (A), Timisoara-Sag (B), Recas-Topolovatu Mare (C) and Hateg zones. Green rectangles mark the other recent earthquakes clusters - some of them can be correlated with significant historical earthquakes shown in Fig. 4 (Lovrin-Teremia, Srbski Ittebej/Serbia, Banloc-Voiteg, Sag-Parta, Moldova Noua, Mehadia-Orsova). Bocsa and Lipova-Siria areas have no known significant seismic history [2]. b) The frequency of occurrence magnitude relationship: the value of the $b$ regression coefficient $(b=0.97)$ is specific for the whole region [2]. 
Hypocentral parameters of the main events recorded in BSR between 2009 and 2013 years.

*Mw computed from spectral analysis; \#Pre-shock: 08.09.2013, $\mathrm{H}=13: 00: 43.8,45.58 / 22.83, \mathrm{~h}=5.1 \mathrm{~km}$, $\mathrm{Mw}=3.6 \pm 0.2, \mathrm{ML}=3.6, \mathrm{MD}=4.3$.

\begin{tabular}{|c|c|c|c|c|c|c|}
\hline \multirow{2}{*}{ Date } & \multirow{2}{*}{$\begin{array}{l}\text { Origin } \\
\text { Time }\end{array}$} & \multicolumn{2}{|c|}{$\begin{array}{l}\text { Geografical } \\
\text { cordinates }\end{array}$} & \multirow{2}{*}{$\begin{array}{l}\text { Focal } \\
\text { Depth } \\
(\mathrm{km})\end{array}$} & \multirow{2}{*}{$\begin{array}{l}\text { Magnitude } \\
\text { Mw* }^{*}\end{array}$} & \multirow{2}{*}{ Observations } \\
\hline & & $\begin{array}{c}\text { LatN } \\
\text { (degree) }\end{array}$ & $\begin{array}{l}\text { LongE } \\
\text { (degree) }\end{array}$ & & & \\
\hline 07.01 .2012 & 054324.7 & 45.70 & 21.15 & 9.8 & $3.1 \pm 0.2$ & $\begin{array}{c}\mathrm{ML}=3.0, \mathrm{MD}=3.8(\mathrm{SE} \text { Timisoara }) \\
\text { after }[21] ; \text { Felt in Timisoara (I=III-IV } \\
\text { EMS) }\end{array}$ \\
\hline 09.01 .2012 & 195624.6 & 45.77 & 21.68 & 12.0 & $3.3 \pm 0.2$ & $\begin{array}{c}\text { ML=3.4, MD=4.0 (E Timisoara, } \\
\text { Topolovatu Mare), after [21] } \\
\text { Felt in Timisoara (I=III EMS), Lugoj, } \\
\text { Buzias. }\end{array}$ \\
\hline 26.03 .2013 & 120716.4 & 45.83 & 21.24 & 5.7 & $2.7 \pm 0.2$ & $\begin{array}{l}\mathrm{ML}=2.6, \mathrm{MD}=3.4(\mathrm{~N}-\mathrm{NE} \text { Timisoara }) \\
\text { Felt in Timisoara } \mathrm{I}=\mathrm{III}-\mathrm{IV} \text { EMS }\end{array}$ \\
\hline 08.09.2013\# & 132213.9 & 45.65 & 22.86 & 7.7 & $4.0 \pm 0.2$ & $\begin{array}{c}\mathrm{ML}=4.1, \mathrm{MD}=4.5 \\
\mathrm{Io}=\mathrm{V}-\mathrm{VI} \text { EMS (computed), Felt in } \\
\text { Hateg and surroundings }\end{array}$ \\
\hline
\end{tabular}

Their fore- and aftershocks show a 2D space distribution on certain alignments or as small areas, specifically defined as Timisoara-Sanandrei, Timisoara-Sag, Recas-Topolovatu Mare and Hateg seismic active zones. These events are the first ones felt in the region since 2002, when a significant $\mathrm{Mw}=4.3(\mathrm{Io}=\mathrm{VII}$ EMS) earthquake occurred in the Moldova Noua area.

Timisoara-Sanandrei zone (23 events, main shock on 26.03.2013) is located north of the city of Timisoara where there is a significant historical seismic activity [2]. A strong earthquake occurred on 19.11.1879 (Mw=5.4) and other one with $\mathrm{M} \approx 5.6$ is mentioned in the historical documents on 20 June 1443. The last one needs additional detailed documentation to localize it more accurately in time and space [2]. It is worth to mention several historical events, which confirm the seismic potential of the local fault system, e.g. 25.04.1846, Mw=4.8, (I=VIVIIEMS); 29.02.1904, Mw=4.5 (I=VIEMS); 27.01.1972 Mw=4.5 (I=VIEMS) and 23.08.1973, $\mathrm{Mw}=4.5$ (I=VIEMS).

Timisoara-Sag zone (23 events, main shock on 07.01.2012) is one of the most dangerous for the city of Timisoara. Here an Mw=5.4 (Iobs=VIII EMS) earthquake hit the city and the neighboring localities on 27.05.1959. This event had a large number of aftershocks that lasted for a long time. In 1960, on 22 October other strong earthquake $(\mathrm{Mw}=5.0)$ occurred in this epicentral area. Since that time the seismicity is characterized by small to moderate events such as the $\mathrm{Mw}=4.5$, 04.01.1978 earthquake and then only the recent one $(\mathrm{Mw}=3.1,07.01 .2013)$. Also, about 23 years ago there was recorded a significant seismic activity with the major event occurred on 06.09.1936 (Mw=5.2 \pm 0.2 , Io=VII EMS) [12].

Recas-Topolovatu Mare zone (92 events, main shock on 09.01.2012) is the largest epicentral area of the four investigated in this work. The recent seismic activity was analyzed on detail by [8]. Historical seismicity confirms the seismic potential of the system faults in this area [6]. The major events recorded are the following [19]: 08.02.1896, $\mathrm{Mw}=4.2 ; 28.11 .1896, \mathrm{Mw}=4.1$; 12.08.1905, $\mathrm{Mw}=4.9 ; 14.01 .1932, \mathrm{Mw}=4.3 ; 01.10 .1956, \mathrm{ML}=4.0 ; 21.01 .1972, \mathrm{Mw}=4.5$. The last earthquake with significant macroseismic effects (Io=VI EMS) occurred near the city of Buzias on 29.11.1988 ( $\mathrm{ML}=3.7)$. Even in the time of writing this paper an earthquake with $\mathrm{ML}=3.2$ (19.03.2014) occurred in this area and it was felt (I=III EMS) in Timisoara.

Hateg zone (111 events, main shock on 08.09.2013) is located in the eastern edge of BSR, within a small Neogene Basin. The historical strong seismicity of the zone is not well known, but some authors localized here several strong earthquakes [2, 29]. Thus, [2] localized nearby Hateg area 
the 19.01.1665 $(\mathrm{Mw}=4.5)$ event even if it is very little documented and the authors of ROMPLUS fixed the epicenter in the Portile de Fier - Orsova zone. Here and in other surrounding zones were, also, located some events with $\mathrm{M} \geq 4.0$. Thus, the earthquakes occurred in the Deva-Mures Valley zone (30.04.1886 and 05.10.1890, $\mathrm{Mw}=4.0)$ and Lupeni-Jiu Valley zone $(20.10 .1909, \mathrm{Mw}=5.0)$ are known. From what we know so far the recently recorded $\mathrm{Mw}=4.0$, 08.09.2013 event is the first local earthquake with certain location that produced macroseismic effects. The 09.07.1912 $(\mathrm{Mw}=5.2, \mathrm{Ms}=4.9)$ appear as a significant event that needs more investigations because it has uncertain locations in Hateg Basin or in Targu Jiu area. Different authors located it in different zones: i) $\mathrm{Ho}=21: 46,45.7 / 22.8, \mathrm{Mw}=5.2$ (Poiana Rusca Mts zone after [2] with corrections), ii) $\mathrm{Ho}=21: 46,45.0 / 23.3, \mathrm{Mw}=4.5$ (Tirgu Jiu zone after ROMPLUS) and iii) $\mathrm{Ho}=21: 46,45.4 / 22.8, \mathrm{Ms}=4.9$ (Hateg zone, after [29]). Even when we wrote this paper for the conference, an earthquake with $\mathrm{ML}=3.0$ occurred in this zone; thus confirming that it is a seismic area to which we must pay a particular attention in the future (monitoring and historical investigations).

We localized on the map displayed in Fig. 3 many other recent earthquakes clusters, such as Lovrin-Teremia, Srbski Ittebej (Serbia-Romania border), Banloc-Voiteg, Sag-Parta, Moldova Noua-Oravita and Mehadia seismic zones. All of them have no significant main event but they were associated with the major historical earthquakes ( $M \geq 4.0 / I \geq V I$ EMS) mapped in Fig. 4 and with the main seismotectonic sources defined and used for seismic hazard assessment by [2].

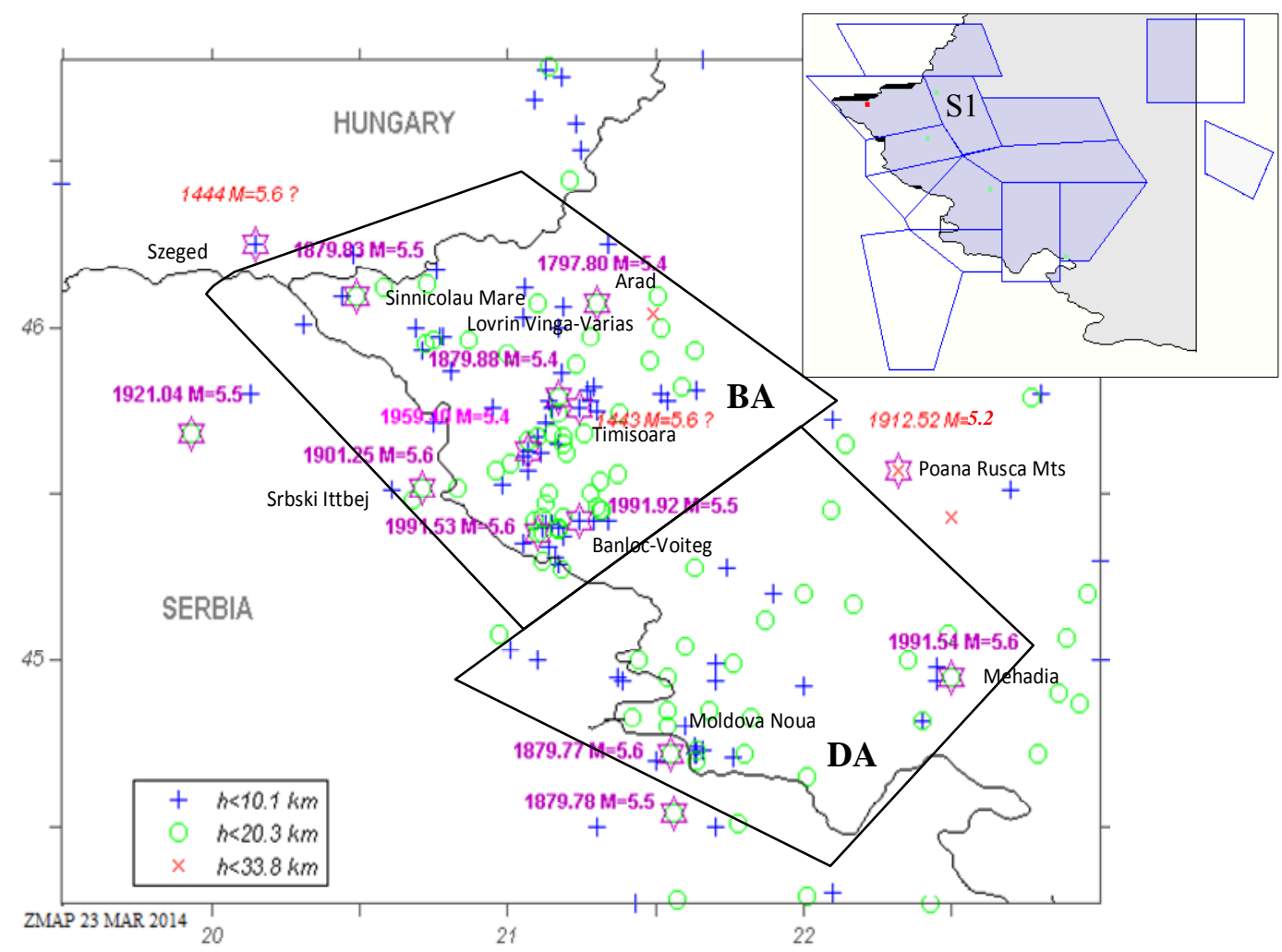

Fig. 4 - Historical seismicity of BSR, Mw $\geq 4.0$ [2] completed with data from this study. Red written earthquakes are uncertain events (Szeged 1444, Timisoara 1443, Poiana Rusca Mountains 1912). BA and DA are Banat Seismogenic Zone and Danube Seismogenic Zone, senso [3]. Insert: the configuration of the seismic hazard sources defined by [2].

We also identified some new zones of recent high seismic activity:

1) The Lipova-Siria zone with two obvious E-W alignments defined by the epicenters distribution;

2) The Bocsa zone with a group of epicenters rather scattered within a small area.

These two seismo-active areas may be connected with human activities, like quarry and/or mining blasts as we before analyzed (Fig. 2). However, the seismic history and the almost linear distributions of the epicenters from Lipova-Siria zone argue their tectonic origin. Thus, the 
following significant earthquakes occurred within or nearby this area [2]: 15.10.1847, $\mathrm{Mw}=5.0$ (Arad), 10.01.1892, Mw=4.6 (Ghioroc-Lipova) and 26.09.1910, Mw=4.7 (Masloc), 19.12.1991, $\mathrm{ML}=4.1$ (Masloc).

Bocsa seismic zone remains a questionable one that needs a future monitoring.

In the central part of BSR, between Siria and Mehadia, where [2] defined a local seismic hazard source (Fig.4, insert), two NNW-SSE oriented alignments of the epicenters distributions can be also observed (Fig. 3). The alignments fit the above mentioned source configuration (S1, Fig 4, insert) and the earthquakes distribution displayed in Fig. $4(\mathrm{~h}<20.3 \mathrm{~km}$, South to Arad and NE to Timisoara). Only one significant, but uncertain, earthquake we know in the zone [2], the $\mathrm{Mw}=5.4,19.10 .1797$ event. We need future seismic monitoring and detailed geological and geophysical investigations to clarify their seismotectonic features.

Generally, seismic activity recorded over last decade in BSR correlates very well with historical seismicity model defined by $\mathrm{Mw} \geq 4.0$ earthquakes and the seismic hazard sources defined by [2]. All zones with high seismic hazard $(M \geq 5.2)$ seem to be very active, especially Mehadia, Timisoara and Banloc-Voiteg (prolonged up to Sag-Parta). Exceptions are Sinnicolau Mare-Arad (28 events, $M m a x=2.8$ ) and Moldova Noua-Oravita (47 events, Mmax=2.6) areas where recent seismic activity is insignificant, both in number and in magnitude of recorded events.

Last events that occurred near Timisoara, the greatest city in the region, are the first ones that produced macroseismic effects after the $\mathrm{Mw}=4.3 / \mathrm{Io}=\mathrm{V}-\mathrm{VI}$ EMS 17.01.1978 earthquake [2]. The city of Timisoara experienced strong effects from the earthquakes occurred in the seismic history. We can mention the following major events:

i. events occurred close to the city, such as the $\mathrm{M}=5.5,1443$ (uncertain event that needs more investigations) and the $\mathrm{Ms}=4.7 / \mathrm{Io}=\mathrm{VII}-\mathrm{VIII}$ EMS, 19.11 .1879 earthquakes;

ii. events occurred far from the city $(27.05 .1959, \mathrm{Mw}=5.4$, Dist=20 km, 12.07.1991, $\mathrm{Mw}=5.5$ and 02.12.1991, $\mathrm{Mw}=5.4$, Dist=35 km).

The larger clusters of recent seismicity (2007-2013, Fig. 3) are localized within the most important seismic hazard sources in the region: Banloc-Voiteg and Mehadia.

A high seismic activity is grouped on the eastern part of Mehadia-Orsova zone but we do not analyze here because it is a source located outside of the studied region.

\section{Conclusions}

The recent and historical seismicity models show an important and continuous seismic activity within the entire investigated region. The recent seismicity model fits the historical one and generally confirms the number, configuration and seismic potential of the newest local seismic hazard sources modelled by [2].

The paper brings data about new zones with high seismic activity that could change and/or improve the known seismotectonic setting and the seismic hazard input.

We will make new observations, detailed documentations and a continuous monitoring of the region for clarifying all uncertainties about historical seismicity and its relationship with recent micro-seismicity and tectonics, especially within Hateg Basin and Siria-Mehadia, LipovaCaransebes and Bocsa areas.

\section{Acknowledgements}

The paper was presented at the "5th National Conference on Earthquake Engineering and the 1st National Conference on Earthquake Engineering and Seismology", June 19-20 2014, Bucuresti”; it was published in the volume of the Conference. 
We used data recorded by the Romanian Seismic Network. Partly, the study was funded by the project "Nucleu" of the National Plan for Research, Development and Innovation of the Romanian Ministry of National Education, Contract no. PN 09-30/27.02.2009.

\section{References}

[1] Ardeleanu L., Leydecker G., Bonjer K., Busche H., Kaiser D. Schmitt R. (2005). Probabilistic seismic hazard map for Romania basis for new building code. Natural Hazards and Earth System Sciences, 5, 679-684.

[2] Oros E. (2011). Researches on seismic hazard for Banat Seismic region (in Romanian). Phd. Thesis unpublished dissertation. University of Bucharest, Bucharest, Romania.

[3] Radulian M., Mandrescu N., Panza G.F., Popescu E., Utale A., (2000). Characterization of Sesimogenic Zones of Romania. Pure and Applied Geophysics, 157, 57-77.

[4] Oros E. (2008). Review of Historical Seismicity in the western and south-western territory of Romania (Banat Seismic Region). Acta Geodaetica et Geofisica Hungarica, 43, 2-3, 153-161, Budapest.

[5] Oros E. (2004). The April-August Moldova Noua earthquakes sequence and its seismotectonic significance. Revue Roumaine de Geophysique, 48, 49-68, Bucharest.

[6] Oros E. (2010). Seismicitatea Regiunii Seismice Banat - Monitorizare, caracteristici, hazard seismic local. Bulletin AGIR, 2-3, 30-35, Bucharest.

[7] Oros E. (2012). Seismicitatea, seismotectonica si hazardul seismic specifice zonei Timisoara. Bulletin AGIR, 3, 16-19, Bucharest.

[8] Oros E. (2013). Analysis of two earthquake sequences occured in 2012 in the Timisoara area, Romania. Romanian Journal of Physics, 58, 7-8, 970-986, Bucharest.

[9] Popescu E., Radulian, M. (2001). Fractal characteristics of time, space and size distributions of the Banat earthquake sequences occurred in 1991. Romanian Journal of Physics; 46(7-8), 485-498;

[10] Toth L., Monus P., Zsiros T., Kiszely M. (2002). Seismicity in the Pannonian Region-earthquake data. EGU Stephan Mueller Special Publication, 3, 9-28.

[11] Zsiros T. (2007). Seismicity of the Banat Region. Acta Geodaetica Geophysica Montanist Hungarica,42,361374, Budapest.

[12] Oros E., Oros V. (2008). The study of the 20th century strong Romanian earthquakes using historical instrumental data-a success of EUROSEISMOS 2002-2006 Project. Proceedings, 31st General Assembly of the ESC 2008 Hersonissos, 7-12 September 2008, 304-311, Crete.

[13] Oros E., (2001). Surse de hazard seismic pentru zona de Vest a României. Anals of Univ. "Eftimie Murgu" Reşiţa, Enginering section, VII, 2, 577-686, Resita.

[14] Oros E., Oros V. (2009). New and updated information about the local hazard seismic sources in the Banat Seismic Region. In Volumul Editat pentru a „4-a Conferinta Nationala de Inginerie Seismica, Bucuresti, 18.12.2009”, Ed. CONPRESS, Vol. 1, 133-139, Bucharest.

[15] Marovic M., Djokovic I., Pesic L., Radovanovic S., Toljic M., Gerzina N. (2002). Neotectonics and seismicity of the southern margin of Pannonian basin in Serbia. EGU Stephan Mueller Special Publication, 3, 277-295.

[16] Atanasiu I (1961). Cutremurele de pământ şi sensibilitatea seismică în România. Ed. Romanian Academy, Bucharest.

[17] Constantinescu L., Cornea I., Lăzărescu V. (1974). Seismotectonic map of Romania. UNDP/UNESCO, Proc. of the seminar on the seismotetctonic map of Balkan Region, Dubrovnik, 17-26 Apr. 1973, 118-137.

[18] Cornea I., Lazarescu V. (1982). Geologia si seismotectonica Romaniei. În "Cutremurul de pamint din Romania de la 4 Martie 1977", Ed. Romanian Academy, Bucharest.

[19] Dimoiu I., Oros E., Nitoiu L. (1997). Cutremurele banatene si acţiunea acestora asupra constructiilor din zona. Ed. Technical University Bucharest, Vol. I, „Conferinta Nationala de Inginerie Seismica”, 18-18.09.1997, 51 62 , Bucharest.

[20] Karnik V. (1968). Seismicity of the European Area. Part 1. Catalogue of earthquakes (1901-1955). Publishing House of the Czechoslocak Academy of Sciences, Praga.

[21] Oros E., Nitoiu L. (1990). Asupra activităţ̧ii seismice în Cîmpia de Vest a României si relaţia ei cu structura geologică. Perioada 1739-1978. Research Report NIEP, Bucharest.

[22] Oros E. (1990a). Activitatea seismică în Cîmpia de Vest a României în perioada 1739-1978. Nat. Conf. of Physics, 24-27.10.1990, Cluj-Napoca.

[23] Oros E. (1990b). Asupra relatiei dintre cîmpul geotermic si seismicitate în Cîmpia de Vest a României. Nat. Conf. of Physics, 24-27.10.1990, Cluj-Napoca.

[24] Oros E. (1991). Activitatea seismică în sud-vestul României si relaţia ei cu structura geologică. Research Report NIEP, 30.86.1/1991, Bucharest.

[25] Polonic G., Malita Z. (1997). Geodynamic processes and seismicity in Banat (Romania). Revue Roumaine de Geophysique, 41, 67-78.

[26] Polonic G. (1985). Neotectonic activity at the Eastern Border of the Pannonian Depression and its seismic implications. Tectonophysics, 47, 109-115, 
[27] Radu C., Oncescu M.C., Utale A., Nitoiu L., Oros E., Petrovici M. (1992). New data about the seismicity of the Banat (Romania) Region. Abstracts, XXIIth General Assemble of ESC, 7-12.10.1992, Praga.

[28] Oros E., Popa M., Moldovan I. A. (2008). Seismological DataBase for Banat Seismic Region (Romania)- Part 1: The Parametric Earthquake Catalogue. Romanian Journal of Physics, 53, 7-8, 955-964, Bucharest.

[29] Shebalin N. V., Leydecker G., Mokrusina N. G., Tatevossian R. E., Erteleva O. O, Vassiliev V. YU. (1998). Earthquake Catalogue for Central-Southeastern Europe 342BC-1990AD. European Commission, Report No. ETNU CT 93 - 0087, Brussels.

[30] Havskov and Ottemoller, SeisAn Earthquake analysis software, Seis. Res. Lett., $70,1999$. http://www.seismosoc.org/publications/SRL/SRL_70/srl_70-5_es.html

[31] Wiemer S, Baer W. (2000). Mapping and removing quarry blast events from seismicity catalogs. Bulletin of Seismological Society of America, 90, 2, 525-530.

[32] Wiemer, S., Zuniga F. (1994). ZMAP-a software package to analyze seismicity. EOS, Transactions, Fall Meeting, AGU, 75, 456. 